\title{
Simple and Partial Correlationships of Nutritional Factors to Serum High-Density Lipoprotein Cholesterol Levels in a Japanese Rural Population
}

\author{
Takeo Nakayama ${ }^{1}$, Chigusa Date ${ }^{2}$, Momoko Yamaguchi ${ }^{3}$, Takashi Yamamoto', \\ Masako Iwaya ${ }^{3}$, Nobuo Yoshi-ike ${ }^{3}$, Edward K. Fujimoto', Tetsuji Yokoyama', \\ Yasuhiro Matsumura ${ }^{3}$, Fukue Seino ${ }^{1}$, Hao Chen', Wakako Kushiro', \\ Ariko Noji ${ }^{4}$, Byung Mann $\mathrm{Cho}^{5}$, and Heizo Tanaka ${ }^{1,3}$
}

\begin{abstract}
After determining the normal ranges of serum high-density lipoprotein cholesterol levels, correlates of HDL-cholesterol were analysed in a sample of 1,283 males and 2,123 females aged 40 years and older in an agricultural area of Shibata City, Niigata Prefecture. The distribution of serum HDL-cholesterol was nearly a log-scale normal distribution curve. The median and the lower and upper normal limits were calculated theoretically and the median values were: $40-49$ age group, $51.9 \mathrm{mg} / 100 \mathrm{ml}$ for males and $52.5 \mathrm{mg} / 100 \mathrm{ml}$ for females ; $50-59$ age group, 52.5 and 51.4 ; 60-69 age group, 51.4 and 49.4 ; over 70 age group, 49.4 and 47.9 . There was almost no difference in HDL-cholesterol levels between both sexes. This was explained as possibly due to alcohol intake raising HDL-cholesterol levels in males. There was a positive association of HDL-cholesterol levels with reported amount of alcohol intake in males. Inverse relationships were found between serum HDL-cholesterol levels and obesity in any age group for both sexes. An inverse correlation between percent energy contribution by carbohydrate and $\mathrm{HDL}$-cholesterol was observed in males. Caloric intake was positively correlated to HDL-cholesterol in females.
\end{abstract}

HDL-cholesterol, alcohol intake, obesity, dietary intake, normal value

Cardiovascular disease epidemiologic studies have reported that serum high-density lipoprotein cholesterol (hereinafter referred to as HDL-cholesterol) is a protective factor against myocardial infarction ${ }^{1,3)}$. If the life-style and environmental factors that raise serum HDL-cholesterol levels are elucidated, primary prevention of coronary heart disease may be possible through control of these factors. Heretofore, however, there have been few studies which have examined the relationship between nutritional factors and serum HDLcholesterol levels. This cross-sectional study was conducted for the purpose of examining that nutritional factors are related to serum HDL-cholesterol levels, after determing the normal ranges of serum HDLcholesterol levels of subjects aged 40 years and older who were engaged in agriculture in Shibata City, Niigata Prefecture, Japan.

\section{SUBJECTS AND METHODS}

Shibata City covers an area of 434 square kilometers and is located in the northern part of Niigata Prefecture. It includes a commercial residential area in the center and an agricultural area around it. For administrative convenience, the agricultural area is divided into eight districts. Four of these districts were inves-

\footnotetext{
Received June 8, 1992 ; accepted July 20, 1992.

'Department of Epidemiology, Medical Research Institute, Tokyo Medical and Dental University, Tokyo, Japan. ${ }^{2}$ Department of Public Health, Osaka City University Medical School, Osaka, Japan. '3Division of Adult Health Science, National Institute of Health and Nutrition, Tokyo, Japan. 'School of Allied Health Science, Tokyo Medical and Dental University, Tokyo, Japan. 'Department of Preventive Medicine, College of Medicine, Pusan National University, Pusan, Korea. Address for correspondence: Heizo Tanaka, Department of Epidemiology, Medical Research Institute, Tokyo Medical and Dental University. 2-3-10 Kanda-Surugadai, Chiyoda-ku Tokyo 101, Japan.
} 
Table 1. Population, number responding and response rate

\begin{tabular}{c|lccccc}
\hline Sex & \multicolumn{1}{|c}{ Age (year) } & $40-49$ & $50-59$ & $60-69$ & $70-$ & Total \\
\hline \multirow{3}{*}{ Males } & Population eligible & 438 & 616 & 475 & 307 & 1836 \\
& Number responding* & 263 & 394 & 385 & 241 & 1283 \\
& Response rate (\%) & 60.0 & 64.0 & 81.0 & 78.5 & 69.9 \\
\hline \multirow{3}{*}{ Females } & Population eligible & 705 & 833 & 680 & 590 & 2808 \\
& Number responding* & 502 & 708 & 593 & 320 & 2123 \\
& Response rate (\%) & 71.2 & 85.0 & 87.2 & 54.2 & 75.6 \\
\hline
\end{tabular}

* number responding to both serum HDL-cholesterol measurement and dietary survey

tigated in this study. The population aged 40 years and over in these four districts were 2,567 males and 3,298 females of whom 1,836 males and 2,808 females were engaged in agriculture. Among these, 1,359 males and 2,246 females received health evaluations for cardiovascular disease at least once between 1981 and 1983. For this study, the following persons were excluded: those who refused to have blood samples taken, those whose serum HDL-cholesterol could not be measured because of imcomplete separation of HDL due to high level of very low density lipoprotein, and those who were not able to complete the dietary survey because of hearing impairment, speech disturbance etc. After exculsion, a total of 1,283 males and 2,123 females remained in the study population (Table 1).

Using venous blood drawn without regard to the time of the previous meal, determination of serum HDL-cholesterol was made by the heparin-manganese chloride method following a standard approach, including analysis as recommended by the $\mathrm{CDC}^{9)}$. In order to maintain quality of control in serum HDLcholesterol measurement, we participated in the CDCNHLBI Lipid Standardization Program through the Osaka Prefectual Center for Adult Diseases. In this lipid standardization program, accuracy and precision for measuring low levels of cholesterol and HDLcholesterol attained the permission criteria.

Histograms of serum HDL-cholesterol levels according to sex and age were developed and examined for type of distribution, and for determination of the statistical normal ranges.

Dietary and alcoholic intakes were assessed by a food frequency survey method which was newly designed by the authors ${ }^{5)}$. Dietitians interviewed subjects regarding food intake frequency, standard serving sizes of food and methods of preparation. The amount of nutrients and foods derived was presumed to be average long-term dietary intake, namely intake over the preceding year.

The degree of over- or under-weight was expressed as the percentage deviation of the actual level (M) from the standard level (S), $\Delta \%=(\mathrm{M}-\mathrm{S}) / \mathrm{S}$. For this study, the standard weight was based on a table of average weights by height and sex developed by Minowa et $\mathrm{al}^{6)}$. The body mas index, $\mathrm{BMI}=($ body weight in $\mathrm{kg}$ ) $\times 10^{4} /(\text { height in } \mathrm{cm})^{2}$, was also calculated. Subcutaneous skinfolds were measured with a calibrated caliper (National Institute of Health and Nutrition, Tokyo). Values for triceps and subscapular skinfolds were individually tabulated and later summed.

Smoking as a confounding variable between dietary intake and serum HDL-cholesterol was recorded as the average number of cigarettes per day.

The relationships between nutritional factors and serum HDL-cholesterol levels were studied with reference to simple and partial correlation coefficients. In order to have the partial correlation coefficients, in males, a multiple regression analysis was done with alcohol intake (per $\mathrm{kg}$ of body weitht), carbohydrate intake (per kg of body weight), BMI and smoking as independent variables, taking into account their correlation to serum HDL-cholesterol levels and other nutritional factors.

In females, the same type of analysis was done with carbohydrate intake (per $\mathrm{kg}$ of body weight), animal fat intake (per $\mathrm{kg}$ of body weight) and BMI and independent variables. For statistical analysis, the SAS statistical package was used.

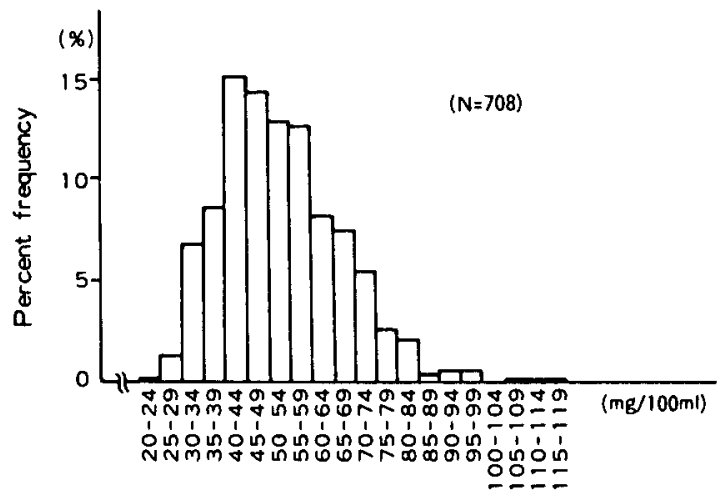

Figure 1. Histogram of Serum High-Density Lipoprotein Cholesterol Distribution in 708 females aged 50 to 59 years. 


\section{RESULTS}

Statistical normal ranges of serum HDL-cholesterol

Percent frequency histograms of serum HDLcholesterol were developed for age and sex. For the sample shown in Figure 1, a distribution closely similar to log-scale normal distribution was suggested. Therefore, HDL-cholesterol values were transformed into logarithms, and the cummulative percent frequency was plotted on a normal probability sheet, the results of which indicated that the distribution of serum HDL-cholesterol was nearly a log-scale normal distribution.

The statistical normal ranges of serum HDLcholesterol were obtained by the following method ${ }^{7}$. Using $X$ transformed into logarithms from serum HDL-cholesterol values, $X$ and $S$ were calculated,

$$
X=\Sigma X_{i} / n, S=\sqrt{\Sigma}\left(X_{i}-X\right)^{2} / n-1 .
$$

Using initial ranges between $X-3 S$ and $X+3 S$, the data beyond this range were then excluded, and mean $\left(X^{\prime}\right)$ and standard deviation $\left(S^{\prime}\right)$ were recalculated. The values $X^{\prime}, X^{\prime} \pm 2 S^{\prime}$, and $X^{\prime} \pm S^{\prime}$ transformed inversely into their original ones were defined as median, the range of $95 \%$ distribution, and the range of $68 \%$ distribution, respectively.

The results of the defined medians, the ranges of $95 \%$ distribution and those of $68 \%$ distribution of serum HDL-cholesterol classified by sex and age are shown in Table 2. The median tended to decrease slightly with age, and this tendency was more pronounced in females than in males. When the subjects aged 40-49 years were excluded, the median was higher in males than in females.

Association of nutritional factors with serum HDLcholesterol levels

The simple correlation coefficients between nutritional factors and serum HDL-cholesterol levels are shown in Table 3-1 for males and Table 3-2 for females. In male subjects, alcohol intake and percent of total energy intake contribution by alcohol were positively and significantly correlated to serum HDLcholesterol levels. Relative weight, BMI and subscutaneous skinfolds were inversely and significantly correlated to HDL-cholesterol. While a significant inverse correlation between percent energy contribution by carbohydrate and HDL-cholesterol was shown, a significant correlation between carbohydrate intake and HDL-cholesterol was not found.

In female subjects, a significant inverse correlation between relative weight, BMI or subcutaneous skinfolds and HDL-cholesterol was seen except for the age group of 40-49 years. The correlation between total energy intake and HDL-cholesterol was also observed. The correlation of major nutrients such as animal protein, animal fat, vegetable fat, iron and calcium to HDL-cholesterol was statistically significantly positive, but not in all age groups.

Results from the multiple regression analysis were shown in Table 4-1 for males and Table 4-2 for females. In males, the partial correlation coefficients for alcohol intake and BMI were statistically significant. The coefficient between smoking and HDL-cholesterol was inverse, but it reached statistical significance only in the age groups of $40-49$ and $60-69$ years.

In females, the partial correlation coefficient for BMI reached statistical significance in all age groups. The coefficient for animal fat was positive and statistically significant in females aged $40-49$ years and 70 years or over.

\section{DISCUSSION}

With the understanding that comparison of median and mean of serum HDL-cholesterol levels of Shibata City with other intra- and inter-country data must be interpreted carefully, because of differences in measuring method, particularly the method of HDL separation, and the state of quality control among the labora-

Table 2. The level of serum HDL-cholesterol by sex and age in an agricultural area of Shibata City, Niigata Prefecture

\begin{tabular}{c|ccccc}
\hline Sex & Age (year) & Mean \pm S.D. & Median & $95 \%$ range & $68 \%$ range \\
\hline \multirow{6}{*}{ Males } & $40-49$ & $53.2 \pm 13.8$ & 51.9 & $30.2-89.1$ & $39.6-68.0$ \\
& $50-59$ & $53.5 \pm 15.1$ & 52.5 & $28.2-97.5$ & $38.5-71.5$ \\
& $60-69$ & $52.7 \pm 14.9$ & 51.4 & $28.7-91.8$ & $38.5-68.7$ \\
& $70-$ & $50.5 \pm 13.8$ & 49.4 & $28.2-86.4$ & $37.3-65.4$ \\
\hline \multirow{5}{*}{ Females } & $40-49$ & $53.5 \pm 12.1$ & 52.5 & $33.1-83.0$ & $41.7-66.0$ \\
& $50-59$ & $52.4 \pm 12.9$ & 51.4 & $30.5-86.4$ & $39.6-66.7$ \\
& $60-69$ & $50.8 \pm 13.7$ & 49.4 & $28.2-86.4$ & $37.3-65.4$ \\
& $70-$ & $48.9 \pm 12.6$ & 47.9 & $28.5-80.6$ & $37.0-62.2$ \\
\hline
\end{tabular}


Table 3-1. Correlation coefficients between nutritional factors and serum HDL-cholesterol in males

\begin{tabular}{|c|c|c|c|c|}
\hline Age & $40-49$ & $50-59$ & $60-69$ & $70-$ \\
\hline No. of samples & 263 & 394 & 385 & 241 \\
\hline \multicolumn{5}{|l|}{ Nutrient (per kg of body weight) } \\
\hline Energy & 0.190 & 0.193 & 0.150 & 0.182 \\
\hline Carbohydrate & 0.085 & 0.027 & -0.026 & 0.026 \\
\hline Animal protein & 0.085 & 0.146 & 0.130 & 0.115 \\
\hline Vegetable protein & 0.115 & 0.094 & 0.039 & 0.115 \\
\hline Animal fat & 0.051 & 0.061 & 0.129 & 0.120 \\
\hline Vegetable fat & -0.061 & 0.082 & 0.066 & 0.123 \\
\hline Iron & 0.079 & 0.133 & 0.091 & 0.110 \\
\hline Calcium & 0.112 & 0.042 & 0.067 & 0.090 \\
\hline Salt & 0.100 & 0.064 & 0.071 & 0.032 \\
\hline Alcohol & $0.313^{*}$ & $0.328^{*}$ & $0.325^{*}$ & $0.308^{*}$ \\
\hline \multicolumn{5}{|l|}{ Food (per kg body weight) } \\
\hline Cereal & 0.152 & 0.044 & 0.017 & 0.036 \\
\hline Rice & 0.145 & 0.074 & 0.019 & 0.014 \\
\hline Potato & -0.005 & 0.040 & 0.054 & -0.015 \\
\hline Sugar & -0.071 & -0.117 & 0.000 & -0.082 \\
\hline Confectionery & -0.092 & -0.057 & -0.164 & 0.027 \\
\hline Oil and fat & -0.033 & 0.057 & 0.109 & 0.089 \\
\hline Miso (soy bean paste) & 0.008 & 0.028 & -0.008 & 0.033 \\
\hline Pulses other than miso & 0.024 & 0.053 & 0.053 & 0.105 \\
\hline Fish & 0.065 & 0.097 & 0.129 & 0.030 \\
\hline Meat & -0.027 & 0.140 & 0.072 & 0.027 \\
\hline Egg & 0.151 & 0.125 & 0.149 & 0.209 \\
\hline Milk & 0.076 & -0.042 & 0.032 & 0.034 \\
\hline Fresh vegetable & 0.052 & 0.149 & 0.117 & 0.100 \\
\hline Salted vegetable & -0.005 & 0.033 & 0.013 & -0.080 \\
\hline Fruits & -0.047 & -0.001 & 0.001 & 0.013 \\
\hline Seaweed & -0.027 & 0.015 & 0.129 & 0.138 \\
\hline $\begin{array}{l}\text { Milk drinks, fruit drinks } \\
\text { and carbonated beverages }\end{array}$ & -0.031 & -0.002 & 0.028 & -0.110 \\
\hline \multicolumn{5}{|l|}{ Caloric percent of } \\
\hline Carbohydrate & -0.147 & $-0.228^{*}$ & $-0.279^{*}$ & $-0.274^{*}$ \\
\hline Animal protein & -0.028 & -0.001 & 0.062 & 0.026 \\
\hline Vegetable protein & -0.125 & -0.138 & -0.182 & -0.169 \\
\hline Animal fat & -0.031 & -0.060 & 0.064 & 0.052 \\
\hline Vegetable fat & -0.199 & -0.042 & -0.006 & 0.081 \\
\hline Alcohol & $0.267^{*}$ & $0.299^{*}$ & $0.292^{*}$ & $0.250^{*}$ \\
\hline \multicolumn{5}{|l|}{ Anthropometry } \\
\hline Relative weight & $-0.251^{*}$ & $-0.251^{*}$ & $-0.333^{*}$ & -0.163 \\
\hline BMI & $-0.252^{*}$ & $-0.248^{*}$ & $-0.328^{*}$ & -0.157 \\
\hline Skinfold thickness & $-0.204^{*}$ & $-0.248^{*}$ & $-0.258^{*}$ & -0.187 \\
\hline Upper arm circumference & -0.186 & -0.078 & $-0.220^{*}$ & -0.155 \\
\hline
\end{tabular}

tories (Some laboratories were not participants in the CDC-NHLBI program.), serum HDL-cholesterol levels for Shibata City were compared (Figure 2) ${ }^{8-24)}$.

The solid lines in Figure 2 indicate populations in Japan and broken lines represent those of Western countries. In male subjects, the levels for Shibata City were positioned near the average or above. In general, the levels for Japanese populations were higher than those of Western countries, and were especially higher in Akita prefecture where the death rate from stroke is high even in Japan. The ratio of HDL-to total-cholesterol in Japan is probably high in view of serum total cholesterol levels in Japan being much lower than those in Western countries.

On the other hand, in female subjects, the HDLcholesterol levels for Shibata City were lower as shown 
Table 3-2. Correlation coefficients between nutritional factors and serum HDL-cholesterol in females

\begin{tabular}{|c|c|c|c|c|}
\hline Age & $40-49$ & $50-59$ & $60-69$ & $70-$ \\
\hline No. of samples & 502 & 708 & 593 & 320 \\
\hline \multicolumn{5}{|l|}{ Nutrient (per kg of body weight) } \\
\hline Energy & 0.144 & $0.201^{*}$ & $0.204^{*}$ & $0.260^{*}$ \\
\hline Carbohydrate & 0.075 & 0.153 & 0.130 & 0.195 \\
\hline Animal protein & $0.211^{*}$ & 0.153 & 0.166 & $0.210^{*}$ \\
\hline Vegetable protein & 0.070 & 0.199 & 0.194 & 0.192 \\
\hline Animal fat & 0.174 & 0.147 & 0.173 & $0.257^{*}$ \\
\hline Vegetable fat & 0.166 & 0.177 & 0.195 & $0.206^{*}$ \\
\hline Iron & 0.139 & $0.203^{*}$ & 0.197 & 0.191 \\
\hline Calcium & 0.140 & 0.179 & $0.214^{*}$ & 0.221 \\
\hline Salt & 0.058 & 0.154 & 0.110 & 0.120 \\
\hline Alcohol & 0.064 & 0.077 & 0.163 & 0.099 \\
\hline \multicolumn{5}{|l|}{ Food (per kg of body weight) } \\
\hline Cereal & 0.046 & 0.143 & 0.095 & 0.137 \\
\hline Rice & 0.035 & 0.107 & 0.030 & 0.129 \\
\hline Potato & 0.012 & 0.141 & 0.102 & 0.072 \\
\hline Sugar & 0.053 & 0.069 & 0.112 & 0.218 \\
\hline Confectionery & 0.018 & 0.017 & 0.082 & 0.082 \\
\hline Oil and fat & 0.135 & 0.127 & 0.116 & 0.161 \\
\hline Miso (soy bean paste) & 0.003 & 0.146 & 0.123 & 0.103 \\
\hline Pulses other than miso & 0.073 & 0.200 & 0.177 & 0.186 \\
\hline Fish & 0.139 & 0.110 & 0.094 & 0.172 \\
\hline Meat & 0.161 & 0.070 & 0.102 & 0.042 \\
\hline Egg & 0.114 & 0.162 & 0.154 & 0.177 \\
\hline Milk & 0.085 & 0.099 & 0.125 & 0.176 \\
\hline Fresh vegetable & 0.070 & 0.158 & 0.123 & 0.112 \\
\hline Salted vegetable & 0.036 & -0.009 & 0.015 & -0.017 \\
\hline Fruits & 0.097 & 0.074 & 0.106 & 0.056 \\
\hline Seaweed & 0.049 & 0.084 & 0.055 & 0.121 \\
\hline $\begin{array}{l}\text { Milk drinks, fruit drinks } \\
\text { and carbonated beverages }\end{array}$ & 0.089 & 0.002 & -0.043 & -0.026 \\
\hline \multicolumn{5}{|l|}{ Caloric percent of } \\
\hline Carbohydrate & -0.148 & -0.064 & -0.152 & -0.123 \\
\hline Animal protein & 0.130 & -0.005 & 0.044 & 0.067 \\
\hline Vegetable protein & -0.114 & -0.001 & -0.028 & -0.116 \\
\hline Animal fat & 0.093 & 0.024 & 0.092 & 0.156 \\
\hline Vegetable fat & 0.097 & 0.049 & 0.081 & 0.034 \\
\hline Alcohol & 0.076 & 0.065 & 0.164 & 0.079 \\
\hline \multicolumn{5}{|l|}{ Anthropometry } \\
\hline Relative weight & -0.196 & $-0.317^{*}$ & $-0.246^{*}$ & $-0.303^{*}$ \\
\hline BMI & -0.199 & $-0.313^{*}$ & $-0.250^{*}$ & $-0.302^{*}$ \\
\hline Skinfold thickness & -0.083 & $-0.242^{*}$ & -0.143 & $-0.274^{*}$ \\
\hline Upper arm circumference & -0.138 & -0.190 & -0.175 & $-0.317^{*}$ \\
\hline
\end{tabular}

* $p<0.05$

in Figure 2, and levels for Japanese populations were lower than those of Western countries. Although in Western countries the difference in HDL-cholesterol levels between both sexes are large, levels for females being higher than for males, there was almost no difference between both sexes in the Japanese polulations, including Shibata City. This has been explained as possibly due to alcohol intake raising
HDL-cholesterol levels in male subjects.

In summary, the results of analysis of simple and partial correlations between nutritional factors and serum HDL-cholesterol levels in this study indicated that there were relatively strong relationships between HDL-cholesterol levels and alcohol intake in male subjects. In females, however, the relationship between HDL-cholesterol levels and alcohol intake 
Table 4-1. Partial correlation coefficients between selected independent variables and serum HDL-cholesterol in males

\begin{tabular}{lcccc}
\hline \multicolumn{1}{c}{ Age (years) } & $40-49$ & $50-59$ & $60-69$ & $70-$ \\
\hline Alcohol (g/body weight $\cdot \mathrm{kg})$ & $0.323^{* *}$ & $0.327^{* *}$ & $0.282^{* *}$ & $0.305^{* *}$ \\
Carbohydrate (g/body weight $\cdot \mathrm{kg})$ & 0.005 & -0.007 & $-0.145^{*}$ & -0.095 \\
BMI & $-0.197^{*}$ & $-0.218^{* *}$ & $-0.352^{* *}$ & $-0.205^{* *}$ \\
Smoking (cigarettes/day) & $-0.162^{*}$ & -0.142 & $-0.106^{* *}$ & -0.086 \\
\hline
\end{tabular}

* $\mathrm{p}<0.05 * *: \mathrm{p}<0.01$

Table 4-2. Partial correlation coefficients between selected independent variables and serum HDL-cholesterol in females

\begin{tabular}{lcccc}
\hline \multicolumn{1}{c}{ Age (years) } & $40-49$ & $50-59$ & $60-69$ & $70-$ \\
\hline Carbohydrate $(\mathrm{g} /$ body weight $\cdot \mathrm{kg})$ & -0.046 & -0.009 & -0.004 & -0.012 \\
Animal fat $(\mathrm{g} /$ body weight $\cdot \mathrm{kg})$ & $0.126^{*}$ & 0.070 & 0.099 & $0.186^{*}$ \\
BMI & $-0.157^{*}$ & $-0.257^{* *}$ & $-0.232^{* *}$ & $-0.207^{* *}$ \\
\hline
\end{tabular}

: $\mathrm{p}<0.05{ }^{* *}: \mathrm{p}<0.01$

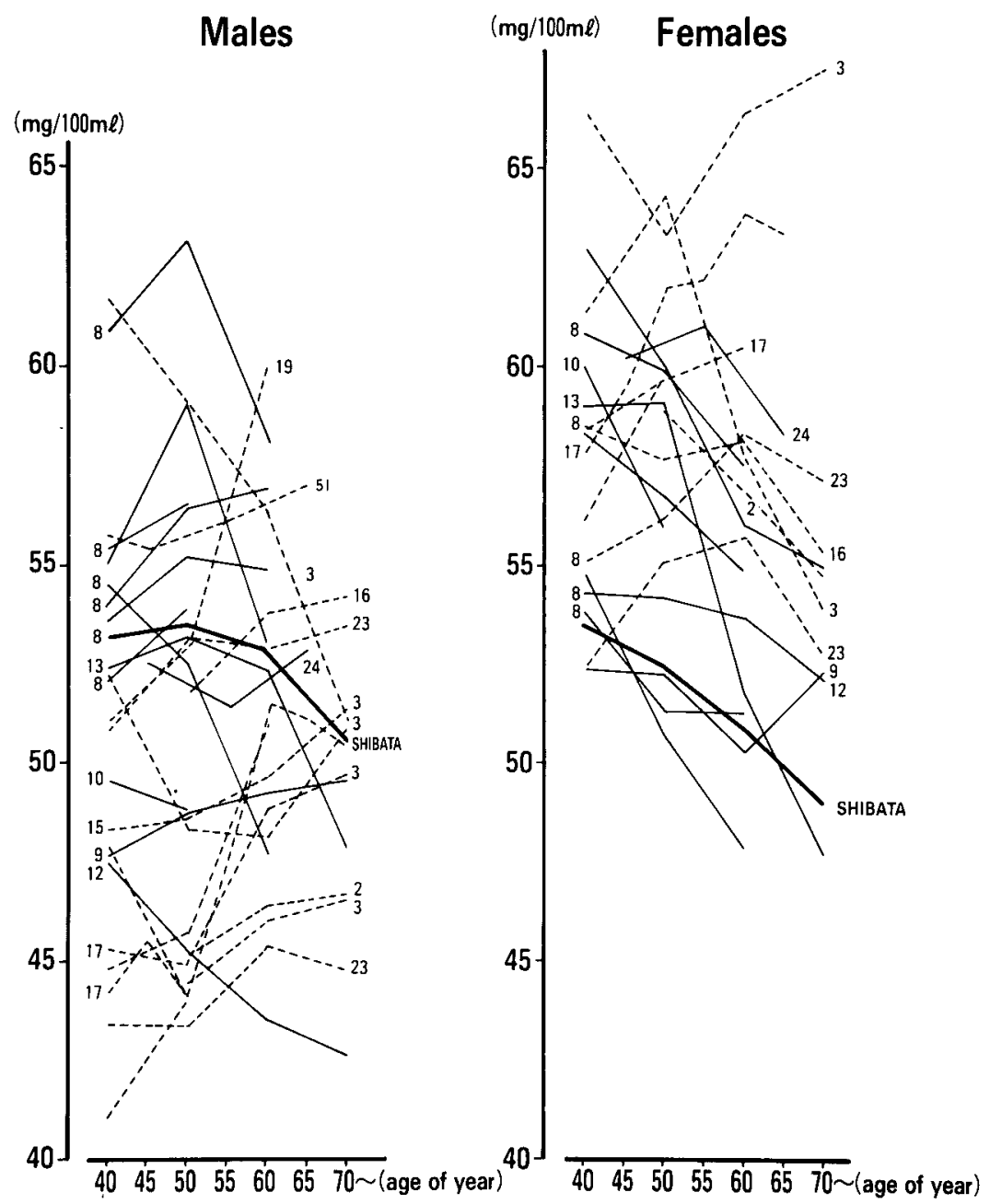

Figure 2. International Comparison of the level of Serum High-Density Lipoprotein Cholesterol by age and sex. — : Populations in Japan, ----: Populations in the U.S. and European countries. Figure at each line: Reference number. 
could not be analysed as there were only 22 habitual drinkers among the 2,123 female subjects in Shibata City at that time.

From the results of Lipid Research Clinics Program Prevalence Study ${ }^{25)}$, Cooperative Lipoprotein Phenotyping Study ${ }^{3}$, and National Health and Nutrition Examinations Survey $\mathrm{II}^{23)}$ in the U.S., the association of alcohol intake with serum HDL-cholesterol level was strong. Similar relationships to alcohol intake were reported for cross-sectional studies in Japan also ${ }^{11,24)}$.

Experimentally it was shown that increasing alcohol intake for long durations raised serum HDLcholesterol levels ${ }^{26,27)}$. The main subfractions of human $\mathrm{HDL}$ are $\mathrm{HDL}_{2}$ and $\mathrm{HDL}_{3}$. Haffner et al. reported no relationship between alcohol consumption and $\mathrm{HDL}_{2}$-cholesterol, but a positive and strong correlation to $\mathrm{HDL}_{3}$-cholesterol ${ }^{28)}$. According to a study by Taskinin et al., moderate habitual intake of less than $40 \mathrm{~g} /$ day of alcohol increased the concentration $\mathrm{HDL}_{3}$ particles ${ }^{29}$. An alcohol loading test showed decreases in serum $\mathrm{HDL}_{2}$-cholesterol and increases in $\mathrm{HDL}_{3}$-cholesterol ${ }^{30}$. Johansson et $\mathrm{al}^{31)}$ found that about 30 percent of alcoholics showed elevation of serum HDL-cholesterol levels, but stated that the composition of this elevated HDL-cholesterol might differ from that of normal HDL-cholesterol. This conclusion is based on the separation of HDL-cholesterol by agarose-gel electrophoresis and antigen-antibody crossing electrophoresis, where electrophoretic patterns of HDL-cholesterol in alcoholics were difference from those in healthy persons. Danielsson et al ${ }^{32)}$ reported that patterns of HDL-cholesterol elevation by alcohol intake varied such as elevation by $\mathrm{HDL}_{2}$-cholesterol alone, and elevation of both $\mathrm{HDL}_{2^{-}}$and $\mathrm{HDL}_{3^{-}}$ cholesterol, and in an ultra-centrifugal separation, a narrow and asymmetric band of $\mathrm{HDL}_{2}$-cholesterol sometimes appeared, or a broad and symmetric $\mathrm{HDL}_{2}$ cholesterol were found out. In addition, in the examination of the composition of the lipid and the protein, it was reported that three patterns were found as follows: increases in apolipoprotein of $\mathrm{HDL}$, increases in cholesterol of HDL, and increases in both. Thus, habitual alcohol drinking can raise serum HDLcholesterol levels, but it may be appropriate to view this elevation as being accompanied by changes in its substance.

Evidences that habitual drinking is one of the environmental causes of hypertension have been accumulating recently ${ }^{33-36)}$. Since hypertension is a strong risk factor for ischemic heart disease and stroke, the effect of alcohol intake on serum HDL-cholesterol levels must be examined within the context that blood pressure levels are also affected by alcohol intake.
Serum HDL-cholesterol levels correlated inversely to relative weight, BMI and skinfold thickness in our present study. Similar inverse correlations between HDL-cholesterol and obesity were epidemiologically found in several studies reported by LRC Study Group ${ }^{37)}$, Rhoads et al. ${ }^{1)}$, Carlson et al. ${ }^{19)}$, and others $^{11,23,24,38,39)}$. In a study of 250 pairs of monozygotic twins ranging in age from 42 to 55 years, researchers found that for an average increase of BMI of $7.3 \%$, there was a $4.9 \%$ decrease in HDL-cholesterol $^{40)}$. In obese women, intra-abdominal (waistto-hip ratio) fat accumulation, independent of total fat, was associated with significantly lower serum HDLcholesterol ${ }^{41}$. In addition, it was reported that weight reduction intervention to prevent coronary heart disease resulted in elevation of HDL-cholesterol ${ }^{39,42)}$.

Hypertriglyceridemia is often found in the obese. Influx of triglyceride-rich lipoprotein into the blood stream is normal or elevated in hypertriglyceridemia, and lipoprotein lipase activities are often suppressed, resulting in decrease in the synthesis of HDL by the pathway from VLDL to HDL and a lowing of serum HDL-cholesterol levels ${ }^{43,44)}$. Even in the case where the activity of lipoprotein lipase is normal, the influx of free cholesterol, phospholipids and apolipoproteins into HDL increases when the influx of triglyceride-rich lipoprotein is activated. The HDL particles become saturated with lipids and apolipoproteins, and become unstable, accelerating the catabolism of HDL and consequently leading to reduced serum HDLcholesterol levels.

For nutritional factors other than alcohol and obesity, energy percentage from carbohydrate inversely and weakly correlated to serum HDL-cholesterol in males. In LRC's investigation ${ }^{25)}$, the amount of carbohydrate, sugar and starch taken also correlated inversely and weakly to HDL-cholesterol. The mechanism of this process was unclear.

In females, serum HDL-cholesterol levels correlated inversely to obesity, and positively but weakly to energy intake. Need for future investigation regarding the relationship energy intake and expenditure to. HDL-cholesterol is indicated. According to the USCanada Collaborative Study ${ }^{45)}$, physical activity as a daily habit positively correlated to HDL-cholesterol independent of other factors. A study indicated that adults who walked for exercise from 2.5 to 4.0 hours or more each week tended to have a $3.4 \%$ increase in HDL-cholesterol level than subjects who did not walk regularly ${ }^{46)}$. There are some reports that serum HDLcholesterol levels in track and field athletes and skiers are higher than those in non-athlete controls ${ }^{47,48}$, that participants in a 1-year running program showed an increase in $\mathrm{HDL}$-cholesterol and $\mathrm{HDL}_{2}$ mass concen- 
trations more than control subjects ${ }^{49}$, and that HDLcholesterol in sedentary workers tended to be low ${ }^{50}$, but with training exercise serum HDL-cholesterol levels could be raised ${ }^{51-53)}$. Brisk walking for 1 year by previously sedentary women for an average of 155 minutes per week resulted in an increase of $27 \%$ in HDL-cholesterol level compared with a $2 \%$ increase in control subjects ${ }^{54}$. Thus, relatively consistent strenuous exercise appears to increase the concentration of HDL-cholesterol in serum.

\section{REFERENCES}

I. Rhoads GG, Gulbrandsen CL, Kagan A. Serum lipoproteins and coronary heart disease in a population study of Hawaii Japanese men. New Engl J Med, 1976; 294 : 293-298.

2. Gordon T, Castelli WP, Hjortland MC. High density lipoprotein as a protective factor against coronary heart disease. Am J Med, 1977; 62 : 707-714.

3. Castelli WP, Doyle JT, Gordon T, et al. HDL cholesterol and other lipids in coronary heart disease, The cooperative lipoprotein phenotyping study. Circulation, 1977; 55: 767-772.

4. Manual of Laboratory Operations, Lipid Research Clinics Program. Vol. 1, Lipid and Lipoprotein Analysis. Bethesda, NHLBI, NIH. DHEW publication no., 1974; (NIH) 75-628.

5. Date C, Tanaka $\mathbf{H}$, Hayashi $M$, et al. A 6.5-year followup study on the relationship between nutrition and cerebral infarction. Osaka City Med J, 1985; 31 : 41-63.

6. Minowa S, Takahashi H, Mayuzumi N, Miyashita $H$. A study on standard weight for adults, Jpn Med J (Nihon Iji Shimpo), 1962 ; No 1988 : 24-28.

7. Barnett RN. Clinical laboratory statistics, Second ed., Little, Brown and Company, Boston, 1979.

8. Iida $\mathbf{M}$, Ueshima $H$, Terao $A$, et al. Effect of serum HDL-cholesterol on occurrence of cardiovascular disease in Japan. Indices of Health and Welfare (Kosei no Shihyo), $1982 ; 28(9): 3-10$.

9. Shibata H, Suyama Y, Matsuzaki T. Analysis of relevant factors of HDL cholesterol. Jpn J Geriatrics, 1981; 18 : 456-461.

10. Tsuji M, Murao M, Ide H, Kobayashi T. Effects of age, sex and obesity on high density lipoprotein cholesterol and phospholipids in normal subjects and in patients with ischemic heart disease. Jpn J Geriatrics, 1980; $17: 639$ 646.

11. Yano $\mathrm{Y}$, Irie $\mathrm{N}$, Honma $\mathrm{Y}$, et al. High density lipoprotein cholesterol level in Japanese. Jpn J Geriatrics, $1979 ; 16: 421-430$.

12. Noma A, Okabe $H$. Effects of age on the concentration of serum HDL-, LDL-and VLDL-cholesterol. J Clin Experi Med (Igaku no Ayumi), 1979; 1091 : 611-613.

13. Sekimoto $H$, Goto $Y$, Naito $C$. Changes of serum total cholesterol and triglyceride levels in normal subjects in Japan in the past twenty years. Research committee on familial hyperlipidemia in Japan. Jpn Circulation $J$ $1983 ; 47: 1351-1358$

14. Takashima $Y$. The significance of serum lipid levels in periodic health examinations. Report 1 The serum HDLcholesterol level as a means of health education. Jpn J
Public Health, 1982 ; 29 : 393-401.

15. Martini $S$, Baggio $G$, Baroni $L$, et al. Evaluation of $\mathrm{HDL}_{2}$ and $\mathrm{HDL}_{3}$ cholesterol by a precipitation procedure in a normal population and in different hyperlipidemic phenotypes. Clin Chem Acta, 1984; 137 : 291-298.

16. Malaspina JP, Bussiere H, Calve GLE. The total cholesterol/HDL cholesterol ratio: A suitable atherogenesis index. Atherosclerosis, $1981 ; 40: 373-375$.

17. Gordon T, Ernst NS, Fisher M, Rifkind BM. Alcohol and high-density lipoprotein cholesterol. Circulation, 1981; 64 (Suppl III) : 63-66.

18. Williams P, Robinson D, Bailey A. High-density lipoprotein and coronary risk factors in normal men. Lancet, $1979 ; 1: 72-75$.

19. Carlson LA, Ericsson M. Quantitative and qualitative serum lipoprotein analysis. Part 1 Studies in healthy men and women. Atherosclerosis, 1975; $21: 417-433$.

20. Wood PD, Haskell W, Klein H, et al. The distribution of plasma lipoproteins in middle-aged male runners. Metabolism, 1976; 25 : 1249-1257.

21. Brunner D, Weisbort J, Loebe K, et al. Serum cholesterol and high density lipoprotein-cholesterol in coronary patients and healthy persons. Atherosclerosis, 1979; 33: 9-16.

22. Heiss G, Johnson NJ, Reiland S, et al. The epidemiology of plasma high-density lipoprotein cholesterol levels. The Lipid Research Clinics Program Prevalence Study. Circulation, 1980; 62 (Suppl IV): 116-136.

23. Linn S, Fulwood R, Rifkind B, et al. High density lipoprotein cholesterol levels among US adults by selected demographic and socioeconomic variables. The Second National Health and Nutrition Examination Survey 19761980. Am J Epidemiol, 1989; 129 : 281-294.

24. Maeda K, Hashimoto S, Okamoto K, et al. The effects of drinking, smoking and physical constitution on high density lipoprotein cholesterol, Apolipoprotein AI and AII levels. Jpn J Hygiene, $1991 ; 46: 699-708$.

25. Ernst N, Fisher M, Smith W, et al. The association of plasma high density lipoprotein cholesterol with dietary intake and alcohol consumption. The Lipid Research Clinics Program Prevalence Study. Circulation, 1980; 62 (Suppl IV): 41-52.

26. Ginsberg H, Olefsky J, Farquhar JW, Reaven GM. Moderate ethanol ingestion and plasma triglyceride levels, A study in normal and hypertriglyceridemic persons. Ann Intern Med, 1974; 80 : 143-149.

27. Belfrage $\mathbf{P}$, Berg B, Hagerstand I, et al. Alternations of lipid metabolism in healthy volunteers during long-term ethanol intake. Eur J Clin Invest, 1977; 7: 127-131.

28. Haffner SM, Applebaum-Bowden D, Wahl PW, et al. Epidemiological correlates of high density lipoprotein subfractions, apolipoprotein A-I, A-II, and D, and lecithin cholesterol acyltransferase. Effects of smoking, alcohol, and adiposity. Arteriosclerosis, 1985; 5 : 169-177.

29. Taskinin MR, Nikkila EA, Valinmaki M, et al. Alcoholinduced changes in serum lipoproteins and in their metabolism. Am Heart J, 1987; 113: 458-464.

30. Yasugi T, Shimizu T. Relevalent factors of serum HDLcholesterol. In : Sakurabayashi ed. HDL-cholesterol. Techno, Tokyo, 1980; 84-102.

31. Johansson BG, Laurell CB. Disorders of serum $\alpha$ lipoproteins after alcoholic intoxication. Scand J Clin Lab Invest, $1969 ; 23$ : 231-233.

32. Danielsson B, Ekman R, Fex G, et al. Change in plasma high density lipoproteins in chronic male alcoholics during 
and after abuse. Scand J Clin, 1978; $38: 113-119$.

33. Clark VA, Chapman JM, Coulson AH. Effects of various factors on systolic and diastolic blood pressure in the Los Angeles Heart Study. J Chron Dis, 1967; 20:571-581.

34. Dyer AR, Stamler J, Paul O, et al. Alcohol consumption, cardiovascular risk factors, and mortality in two Chicago epidemiologic studies. Circulation, 1977; 56: 1067 1074.

35. Klatsky AL, Friedman GD, Siegelaub A, Gềrard MJ. Alcohol consumption and blood pressure, Kaiserpermanent multiphasic health examination data. New Engl J Med, 1977 ; 296 : 1194-1200.

36. Harburg E, Ozgaren F, Hawthorne VM, Schork MA. Community norms of alcohol usage and blood pressure, Tecumseh, Michigan. Am J Public Health, 1980; 70: 813-820.

37. Ueshima $\mathbf{H}$, Shimamoto $\mathbf{T}$, Iida $\mathbf{M}$, et al. Alcohol intake and hypertension among urban and rural Japanese populations. J Chronic Dis, 1984; 37 : 585-592.

38. Glueck CJ, Taylor HL, Jacobs D, et al. Plasma highdensity lipoprotein cholesterol, Association with measurements of body mass, The Lipid Research Clinics Program Prevalence Study. Circulation, 1980; 62 (Suppl. IV) : 62-69.

39. Logan RL, Riemersma RA, Thomson $M$, et al. Risk factors for ischemic heart disease in normal men aged 40 . Edinburgh-Stockholm Study. Lancet, 1978 ; 1 : 949-954.

40. Hulley SB, Cohen R, Widdowson G. Plasma high-density lipoprotein cholesterol level, Influence of risk factor intervention. JAMA, 1977; 238: 2269-2271

41. Newman B, Selby JV, Quesenberry CP, et al. Nongenetic influences of obesity on other cardiovascular disease risk factors. An analysis of identical twins. Am J Public Health, 1990; 80: 675-678.

42. Després JP, Moorjani S, Lupien RJ, et al. Regional distribution of body fat, plasma lipoproteins, and cardiovascular disease. Arteriosclerosis, 1990; 10:497-511.

43. Wolf RN, Grundy SM. Influence of weight reduction on plasma lipoprotein in obese patients. Arteriosclerosis, 1983; 3: 160-169.

44. Tall AR, Small DM. Current concepts, plasma highdensity lipoproteins. New Engl J Med, 1978; 299:
$1232-1236$.

45. Nikkilä EA. Metabolic regulation of plasma high-density lipoprotein concentrations. (editorial). Eur J Clin Invest. $1978 ; 8: 111$.

46. Haskell WL, Taylor HL, Wood PD, et al. Strenuous physical activity, treadmill exercise test performance and plasma high-density lipoprotein cholesterol. The Lipid Research Clinics Program Prevalence Study. Circulation, 1980; 62 (Suppl. IV): 53-61.

47. Tucker LA, Friedman GM. Walking and serum cholesterol in adults. Am J Public Health, 1990; 80: 11111113.

48. Wood PD, Haskell WL, Stern MP, et al. Plasma lipoprotein distributions in male and female runners. Ann NY Acad Sci, $1977 ; 301$ : 748-763.

49. Lehtonen A, Viihari J. Serum triglycerides and cholesterol and serum high-density lipoprotein cholesterol in highly physically active men. Acta Med Scand, 1978; 204: 111-114.

50. Williams PT, Krauss RM, Vranizan KM, et al. Effects of exercise induced weight loss on low-density lipoprotein subfractions in healthy men. Arteriosclerosis, 1989; 9: 623-632.

51. Williams P, Robinson D, Bailey A. High-density lipoprotein and coronary risk factors in normal men. Lancet, 1979 ; 1 : 72-75.

52. Leon AS, Conrad J, Hunninghake DB, Serfass R. Effects of a vigorous walking program on body composition and carbohydrate and lipid metabolism of obese young men. Am J Clin Nutr, 1979; 32: 1776-1787.

53. Huttunen JK, Lansimies E, Volutilainen $E$, et al. Effect of moderate physical exercise on serum lipoproteins. A controlled clinical trial with special reference to serum high-density lipoproteins. Circulation, $1979 ; 60: 1220$ 1229.

54. Wood PD, Haskell WL. The effect of exercise on plasma high-density lipoproteins. Lipids, 1979; 14: 417-427.

55. Hardman AE, Hudson A, Jones PRM, et al. Brisk walking and plasma high-density lipoprotein cholesterol concentration in previously sedentary women. BMJ, 1989 ; 299 : 1204-1205. 